Volume 2 Nomor 2, November 2021: h. 102 - 108 P-ISSN: 2722-4465, E-ISSN: 2746-8151

Lisensi Creative Commons Atribusi-NonCommercial 4.0 Internasional

\title{
Mediasi Sebagai Penyelesaian Sengketa Cerai
}

\section{Ronald Fadly Sopamena}

Fakultas Hukum Universitas Pattimura, Ambon, Indonesia

E-mail: rfsopamena@gmail.com

\begin{tabular}{l}
\multicolumn{1}{c}{ Dikirim: $12 / 10 / 2021$} \\
\hline Info Artikel \\
\hline Keywords: \\
Divorce; Mediation; \\
Reconciliation. \\
DOI: \\
10.47268/ballrev.v2i2.622 \\
\hline \\
Kata Kunci: \\
Perceraian; Mediasi;
\end{tabular}

Direvisi: 30/10/2021

Dipublikasi: $27 / 11 / 2021$

\begin{abstract}
Husband and wife are obliged to love each other, respect, be loyal and provide spiritual and physical assistance to each other. However, sometimes husbands and wives who live the ark of the household often experience complicated conflicts so that divorce is considered the best solution. The purpose of this study is to analyze the peace deed No. 7/Pdt.G/2020/PN Drh. The method for this research is descriptive analytical with normative juridical research using primary, secondary and tertiary data through literature and document studies. The results showed that the divorce lawsuit was processed at the Highlands District Court of Honipopu in West Seram Regency, Maluku Province. The divorce lawsuit finally ended with an agreement between the parties to end the divorce dispute which was resolved through mediation. The peace is stated in the Deed of Peace Number 7/Pdt.G/2020/PN Drh which applies as befits an agreement and has legal consequences if it is not obeyed.
\end{abstract}

\begin{tabular}{l}
\hline Abstrak \\
\hline Suami Istri wajib saling cinta-mencintai hormat-menghormati, \\
setia dan memberi bantuan lahir bathin yang satu kepada yang \\
lain. Namun adakalanya suami dan istri yang menjalani bahtera \\
rumah tangga sering mengalami konflik yang pelik sehingga \\
perceraian dianggap sebagai jalan keluar terbaik. Tujuan \\
penelitian ini menganalisis akta perdamaian Nomor \\
$7 /$ Pdt.G/2020/PN Drh. Metode untuk penelitian ini bersifat \\
deskriptif analitis dengan jenis penelitian juridis normatif dengan \\
menggunakan data primer, sekunder dan tersier melalui studi \\
kepustakaan dan dokumen. Hasil penelitian menunjukan bahwa \\
gugatan cerai yang diproses pada Pengadilan Negeri Dataran \\
Tinggi Honipopu pada Kabupaten Seram Bagian Barat, Provinsi \\
Maluku. Gugatan cerai tersebut akhirnya berakhir dengan \\
tercapainya kesepakatan diantara para pihak untuk mengakhiri \\
sengketa cerai yang diselesaikan melalui mediasi. Perdamaian \\
tersebut tertuang dalam Akta Perdamaian Nomor \\
7/Pdt.G/2020/PN Drh yang berlaku sebagaimana layaknya \\
sebuah perjanjian dan memiliki akibat hukum jika tidak dipatuhi.
\end{tabular}




\section{Pendahuluan}

Manusia sebagai makhluk social mempunyai naluri untuk selalu ingin hidup bersama dan saling berinteraksi dengan sesamanya dan perkawinan adalah sah menurut agama dan kepercayaannya (Labetubun \& Fataruba, 2020: 57). Perkawinan ialah ikatan lahir bathin antara seorang pria dengan seorang wanita sebagai suami isteri dengan tujuan membentuk keluarga (rumah tangga) yang bahagia dan kekal berdasarkan Ketuhanan Yang Maha esa. Seperti itulah yang tertera dalam Pasal 1 Undang-Undang Perkawinan Nomor 1 Tahun 1974 Tentang Perkawinan.

Perkawinan mengakibatkan suatu ikatan hak dan kewajiban, juga menyebabkan suatu bentuk kehidupan bersama dari para pribadi yang melakukan hubungan perkawinan (Mushafi \& Faridy, 2021: 45). Setiap perkawinan yang dilakukan ada yang berakhir sampai maut memisahkan namun ada juga yang hanya sesaat kemudian bercerai (Latupono, 2020: 242). Suami Istri wajib saling cintamencintai hormat-menghormati, setia dan memberi bantuan lahir bathin yang satu kepada yang lain. Namun adakalanya suami dan istri yang menjalani bahtera rumah tangga sering mengalami konflik yang pelik sehingga perceraian dianggap sebagai jalan keluar terbaik.

Fenomena kehidupan rumah tangga yang terjadi salah paham, perselisihan, pertengkaran, yang berkepanjangan sehingga memicu perceraian yang mengakibatkan putusnya hubungan antara suami istri (Latupono, 2020a: 60). Konflik dalam bahasa hukum atau secara yuridis formal disebut dengan istilah sengketa (Sembiring, 2011: 3). Setiap orang, baik suka dan tidak suka bisa saja mengalami konflik. Bermacam cara orang untuk menyelesaiakan sengketa yang sedang dihadapi. Namun semuanya mempunyai tujuan yang sama yaitu untuk menyelesaikan sengketa (Sumardika, 2014: 490).

Sengketa bisa membuat seseorang memutuskan untuk mencari keadilan melalui lembaga pengadilan dengan harapan pengadilan bisa memutuskan secara adil. Berbicara mengenai sengketa, Mahkamah Agung telah merubah paradigma mengadili menjadi paradiga menyelesaikan sengketa/perkara hukum. Penyelesaian sengketa perkara perdata melalui litigasi mulai ditinggalkan dan beralih ke Alternative Dispute Resolution/ADR (Saifullah, 2015: 182).

PERMA Nomor 1 Tahun 2016 mengamanatkan perkara yang wajib menempuh mediasi termasuk perkara cerai. Dengan demikian, setiap gugatan perceraian yang masuk di pengadilan akan langsung menempuh proses mediasi terlebih dahulu. Hal ini tidak berbeda pada suatu gugatan cerai yang diproses pada Pengadilan Negeri Dataran Tinggi Honipopu pada Kabupaten Seram Bagian Barat, Provinsi Maluku. Gugatan cerai tersebut akhirnya berakhir dengan tercapainya kesepakatan diantara para pihak untuk mengakhiri sengketa dan berujung pada dikeluarkannya Putusan Pengadilan berupa Akta Perdamaian Nomor 7/Pdt.G/2020/PN Drh antara Herlin S Monaten sebagai pihak pertama dan Benhard N Latumakulita sebagai pihak kedua. Penelitian ini berusaha menjawab seperti apakah analisis pada Akta Perdamaian Nomor 7/Pdt.G/2020/PN Drh. 


\section{Metode Penelitian}

Peter Mahmud Marzuki, mengatakan bahwa penelitian hukum adalah sesuatu proses untuk menemukan aturan hukum, prinsip-prinsip hukum maupun doktrindoktrin hukum guna menjawab isu hukum yang di hadapi (Marzuki, 2016: 35). Metode untuk penelitian ini bersifat deskriptif analitis dengan jenis penelitian juridis normatif dengan menggunakan data primer, sekunder dan tersier melalui studi kepustakaan dan dokumen.

\section{Hasil dan Pembahasan}

\subsection{Mediasi sebagai Penyelesaian Sengketa Cerai}

Pengadilan masih belum bisa menjalankan amanat Undang-Undang Nomor 4 Tahun 2004 Tentang Kekuasaan Kehakiman untuk menerapkan sistem pengadilan yang sederhana, cepat dan biaya ringan. Hal ini disebabkan karena banyaknya kasus yang dialami masyarakat dewasa ini sangat meningkat baik dari segi kualitas maupun kuantitas sehingga pengadilan yang bertugas memeriksa dan mengadili perkara cukup kesulitan. Salah satu jalan keluar untuk mengatasi keadaan tersebut, yaitu dengan penyelesaian sengketa alternatif di luar pengadilan. Sistem penyelesaian sengketa alternatif di luar pengadilan harus dilakukan dan merupakan suatu kewajiban yang tidak bisa ditawar-tawar lagi (Mustarin, 2020: 28).

Peraturan Mahkamah Agung Nomor: 2 Tahun 2003 yang kemudian diperbaharui dengan peraturan Mahkamah Agung (PERMA) Nomor 1 Tahun 2008 dan kemudian karena PERMA ini dinilai belum optimal memenuhi kebutuhan pelaksanaan mediasi yang lebih berdaya guna dan mampu meningkatkan keberhasilan mediasi di pengadilan, maka dperbaharui lagi dengan Peraturan Mahkamah Agung No. 1 Tahun 2016, tentang Prosedur Mediasi Di Pengadilan.

Melalui PERMA ini, mediasi dimasukkan kedalam proses peradilan formal, bahwa semua perkara perdata wajib terlebih dahulu diupayakan penyelesaian melalui mediasi sebagaimana ditentukan dalam pasal 4 ayat (1) PERMA No.1 Tahun 2016. Pasal 4 ayat (1) PERMA No.1 Tahun 2016 ditentukan jenis perkara wajib menempuh mediasi dan yang dapat dikecualikan adalah:

1) Semua sengekta perdata yang diajukan ke pengadilan termasuk perkara perlawanan (verzet) atas putusan verstek dan perlawanan pihak berperkara (partij verzet) maupun pihak ketiga (derden verzet) terhadap pelaksanaan putusan yang telah berkekuatan hukum tetap, wajib terlebih dahulu diupayakan penyelesaian melalui mediasi, kecuali ditentukan lain berdasarkan peraturan Mahkamah Agung ini.

2) Sengketa yang dikecualikan dari kewajiban penyelesaian melalui mediasi sebagaimana dimaksud pada ayat (1) meliputi:

a) Sengketa yang pemeriksaannya dipersidangan ditentukan tenggang waktu penyelesaiannya meliputi antara lain:

(1) Sengketa yang diselesaikan melalui prosedur Pengadilan Niaga;

(2) Sengketa yang diselesaikan melalui prosedur Pengadilan Hubungann Industrial; 
(3) Keberatan atas putusan komisi pengawa persaingan Usaha;

(4) Keberatan atas putusan Badan Penyelesaian Sengketa Konsumen;

(5) Permohonan pembatan putusan Arbitrase;

(6) Keberatan atas putusan Komisi Informasi;

(7) Penyelsaian perselisihan portal politik;

(8) Sengketa yang diselesaikan melalui tata cara gugatan sederhana; dan

(9) Sengketa lain yang pemeriksaannya di persidangan tenggang waktu penyelesaiannya dalam ketentuan peraturan perundangundangan;

b) Sengketa yang dilakukan tanpa hadirnya pengugat atau tergugat yang telah dipanggil secara patut;

c) Gugatan balik (rekonvensi) dan masuknya pihak ketiga dalam suatu perkara (intervensi);

d) Sengketa mengenai pencegahan, penolakan, pembataan dan pengesahan perkawinan;

e) Sengketa yang diajukan ke pengadilan setelah diupayakan penyelesaian di luar pengadilan melalui mediasi dengan bantuan mediator bersertifikat yang terdaftar di pengadilan setempat, tetapi dinyatakan tidak berhasil berdasarkan pernyataan yang ditandatangani oleh para pihak dan mediator bersertifikat.

3) Pernyataan ketidakberhasilan mediasi sebagaimana dimaksud pada ayat (2) huruf e dan salinan sah sertifikat mediator dilampirkan dalam surat gugatan.

4) Berdasarkan kesepakatan para pihak, sengketa yang dikecualikan kewajiban mediasi sebagaimana dimaksud pada ayat (2) huruf a, huruf c, dan huruf e tetap dapat diselesaikan melalui mediasi sukarela pada tahap pemeriksan perkara dan tingkat upaya hukum.

Tidak seperti pengadilan, mediasi diterapkan untuk mendapatkan win-win solution bagi para pihak. Maksud dari win-win solution tersebut adalah mediator akan berusaha mencari jalan tengah yang sama-sama menguntungkan para pihak. Jalan tengah yang dimaksud sama dengan pengertian mediasi itu sendiri yang dari bahasa latin "mediare" yang berarti berada di tengah (Abbas, 2009: 2).

Tahapan proses mediasi diatur dalam Bab V PERMA No. 1 Tahun 2016. Pada tahap proses mediasi ini, dalam Pasal 24 ayat (1) sampai dengan ayat (4) dinyatakan bahwa dalam waktu paling lama 5 (lima) hari kerja setelah pemilihan atau penunjukan mediator, para pihak wajib menyerahkan resume perkara kepada pihak lain dan mediator. Proses mediasi dilaksanakan paling lama 30 hari. Jika jangka waktu tersebut dirasa kurang cukup dan masalah belum memiliki titik temu, maka waktu mediasi dapat diperpanjang selama 30 hari kerja. Jika mediasi berhasil mencapai kesepakatan, sesuai dengan Pasal 27 ayat (1) dan (3), para pihak yang bersengketa dan menemukan titik temu, maka dengan bantuan mediator wajib merumuskan kesepakatan secara tertulis yang selanjutnya disebut kesepakatan perdamaian. Kesepakatan harus dibuat secara tertulis, agar jika ada pihak yang 
mengingkarinya, maka dokumen kesepakatan tersebut dapat dijadikan alat bukti untuk menuntutpelaksanan kesepakatan yang telah dibuat (Mardhiah, 2011: 168). Kesepakatan perdamaian tersebut ditandatangani semua pihak termasuk mediator. Jika dalam mediasi tersebut terdapat pihak yang diwakili oleh pengacara atau kuasa hukum, maka pihak tersebut wajib menyertakan secara tertulis yang berisi persetujuan terhadap kesepakatan yang telah dicapai (Mulyana, 2019: 190).

Praktik dalam penyelenggaraan peradilan yang diharapkan di Indonesia sistem peradilan yang efisien dengan asas sederhana dan cepat serta baiaya ringan. Tuntutan implementasi dari pada asas peradilan yang dilakukan secara sederhana, cepat dan biaya ringan semata-mata guna mewujudkan sistem administrasi pengadilan yang efisien terutama dalam rangka mengarahkan pada keadilan dalam pelayanan birokrasi yang baik, khusunya di bidang administrasi perkara perdata (Ahyani et al., 2021: 57). Sehingga, mediasi bisa dipakai sebagai penyelesaian sengketa cerai sehingga penyelesaian sengketa cerai tidak perlu melalui proses dan tahapan yang panjang.

\subsection{Analisis Akta Perdamaian Nomor 7/Pdt.G/2020/PN Drh}

Pada Akta Perdamaian Nomor 7/Pdt.G/2020/PN Drh tertuang kesepakatan antara 2 belah pihak yaitu Penggugat dan Tergugat untuk mengakhiri sengketa cerai. Pada dasarnya, Akta Perdamaian adalah sebuah perjanjian yang dibuat oleh 2 pihak atau lebih. Dimana pada akta tersebut secara jelas tertuang bahwa kedua belah pihak sepakat untuk rujuk dan saling memaafkan satu sama lain serta kembali hidup bersama dalam ikatan perkawinan. Pihak tergugat dengan ini juga telah mengakui kesalahannya dan berjanji tidak akan mengulangi kesalahannya serta bersedia memperbaiki dirinya terutama mengenai kesalahan yang telah diperbuatnya dan juga melanjutkan hubungan perkawinan dengan penuh kasih sayang dan membesarkan anak hasil perkawinan mereka dengan baik.

Seseorang bebas untuk membuat perjanjian dengan pihak manapun yang dikehendakinya sebagaimana asas kebebasan berkontrak, undang-undang hanya mengatur orang-orang tertentu yang tidak cakap untuk membuat perjanjian, maka setiap orang bebas untuk memilih pihak yang diinginkan untuk membuat perjanjian, asalkan pihak tersebut bukan pihak yang tidak cakap (Sopamena, 2021: 11). Jika ditelaah lebih jauh, Akta Perdamaian Nomor 7/Pdt.G/2020/PN Drh sudah sesuai dengan syarat sahnya suatu perjanjian yang diamanatkan pada Pasal 1320 KUH Perdata, bahwa:

Supaya terjadi persetujuan yang sah, perlu dipenuhi empat syarat:

1) kesepakatan mereka yang mengikatkan dirinya;

2) kecakapan untuk membuat suatu perikatan;

3) suatu pokok persoalan tertentu;

4) suatu sebab yang tidak terlarang

Syarat kesepakatan bisa terlihat dari kedua belah pihak yang menandatangani akta tersebut secara sukarela. Sedangkan pada syarat kedua atau syarat cakap maka kedua pasangan suami istri ini merupakan orang yang secara hukum dianggap 
cakap karena tidak ada laporan bahwa salah satu atau kedua pihak berada di bawah pengampuan.

Pokok persoalan sebagai syarat ketiga sahnya akta perdamaian ini diatur di dalam 11 Pasal yang tertulis secara jelas dalam akta tersebut. Isi dari akta perdamaian ini menerangkan bahwa kedua pihak sepakat untuk mengakhiri sengketa mereka dimana pihak kedua mengakui kesalahannya dan berjanji akan memperbaiki diri dan menyatakan bahwa jika pihak kedua mengulangi kesalahannya maka pihak kedua akan memberikan hak asuh anak hasil perkawinan dari para pihak.

Pihak pertama secara jelas juga telah memaafkan kesalahan dari pihak pertama dan permasalahan yang timbul dikemudian hari akan diselesaikan secara kekeluargaan. Pada bagian Putusan, Pengadilan Negeri mengadili perkara tersebut diselesaikan secara damai, menghukum kedua belah pihak yang berperkara untuk mentaati isi kesepakatan perdamaian tertanggal 23 Juli 2020 dan yang terakhir membebankan biaya perkara sebesar Rp. 1.143.000,- (satu juta seratus empat puluh tiga ribu rupiah) kepada pihak yang berperkara.

Mengenai syarat keempat atau syarat suatu sebab yang halal, maka akta perdamaian ini bukanlah suatu hal yang melanggar hukum dan norma-norma kesopanan dan kesusilaan sehingga dengan demikian Akta yang dibuat oleh kedua belah pihak berlaku dan mengikat para pihak sehingga pihak yang melanggar akan menerima konsekuensi hukum.

\section{Kesimpulan}

Penyelesaian sengketa di pengadilan, wajib terlebih dahulu diupayakan penyelesaian melalui mediasi, hal ini termasuk sengketa cerai di Pengadilan Negeri Dataran Tinggi Honipopu pada Kabupaten Seram Bagian Barat, Provinsi Maluku. Salah satu sengketa cerai yang dapat diselesaikan melalui mediasi adalah antara Herlin S Monaten dan Benhard N Latumakulita yang berakhir damai. Perdamaian tersebut tertuang dalam Akta Perdamaian Nomor 7/Pdt.G/2020/PN Drh yang berlaku sebagaimana layaknya sebuah perjanjian dan memiliki akibat hukum jika tidak dipatuhi.

\section{Daftar Referensi}

Abbas, S. (2009). Mediasi Dalam Perspektif Hukum Syariah, Hukum Adat Dan Hukum Nasional. Kencana Prenada Media Group.

Ahyani, H., Makturidi, M. G., \& Muharir, M. (2021). Administrasi Perkara Perdata Secara E-Court di Indonesia. Batulis Civil Law Review, 2(1), 56-65. https:// doi.org/10.47268/ballrev.v2i1.521

Labetubun, M. A. H., \& Fataruba, S. (2020). Implikasi Hukum Putusan Pengadilan terhadap Pembatalan Perkawinan. Batulis Civil Law Review, 1(1), 54-59. https:/ / doi.org/10.47268/ballrev.v1i1.430

Latupono, B. (2020a). Akibat Hukum dalam Perkawinan yang Dilakukan oleh Suami Tanpa Ijin Istri Sahnya. Batulis Civil Law Review, 1(1), 60-67. 
https:// doi.org/10.47268/ballrev.v1i1.431

Latupono, B. (2020b). Pertanggungjawaban Hukum Ayah Terhadap Anak Setelah Terjadinya Perceraian. SASI, 26(2), 242-250. https:// doi.org/10.47268/sasi.v26i2.281

Mardhiah, A. (2011). Penyelesaian Sengketa Melalui Mediasi Berdasarkan Perma No. 1 Tahun 2008. Kanun: Jurnal Ilmu Hukum, 13(1), 153-169.

Marzuki, P. M. (2016). Penelitian Hukum,. Kencana. https://doi.org/340.072

Mulyana, D. (2019). Kekuatan Hukum Hasil Mediasi Di Dalam Pengadilan Dan Di Luar Pengadilan Menurut Hukum Positif. Jurnal Wawasan Yuridika, 3(2), 177198. https:/ / doi.org/10.25072/jwy.v3i2.224

Mushafi, M., \& Faridy, F. (2021). Tinjauan Hukum atas Pembagian Harta Gono Gini Pasangan Suami Istri yang Bercerai. Batulis Civil Law Review, 2(1), 43-55. https:// doi.org/10.47268/ballrev.v2i1.473

Mustarin, B. (2020). Kedudukan Mediasi Sebagai Alternative Dispute Resolution Terhadap Pencegahan Perkara Cerai. Iqtishaduna: Jurnal Ilmiah Mahasiswa Hukum Ekonomi Syari'ah, 2(3), 26-36. https:// doi.org/10.24252/iqtishaduna.v2i3.20029

Saifullah, M. (2015). Efektivitas Mediasi Dalam Penyelesaian Perkara Perceraian Di Pengadilan Agama Jawa Tengah. Al-Ahkam, 25(2), 181-204. https:/ / doi.org/10.21580/ahkam.2015.25.2.601

Sembiring, J. J. (2011). Penyesaian Sengketa di Luar Pengadilan. Visi Media.

Sopamena, R. F. (2021). Kekuatan Hukum MoU Dari Segi Hukum Perjanjian. Batulis Civil Law Review, 2(1), 1-15. https:/ / doi.org/10.47268/ballrev.v2i1.451

Sumardika, A. A. N. R. (2014). Integrasi Lembaga Penyelesaian Sengketa Alternatif dalam Proses Acara Peradilan Perdata: Studi Tentang Putusan Pengadilan yang di Mediasi Berdasarkan Perma Nomor 1 Tahun 2008. Jurnal Magister Hukum Udayana, 7(3), 487-498. 